\title{
Investigation on Mechanical Properties and Wear Behaviour of Titanium Diboride Reinforced Composites
}

Faculty of Mechanical Engineering K.Ramakrishnan college of engineering India

Jafrey Daniel D
Assistant Professor
Faculty of Mechanical Engineering
K.Ramakrishnan college of engineering
India

M. Ravichandran

Associate Professor Faculty of Mechanical Engineering K.Ramakrishnan college of engineering

Aluminium Metal Matrix Composites (AMMCs) are popular materials for aviation and automotive sectors due to their enhanced strength to weight ratio, increased resistance to corrosion and better tribological properties. In this work, the AA7075 alloy was reinforced with Titanium Boride (TiB2) particles $(0,4,8,12 \mathrm{wt}$. \%) via stir casting process. In this process, the preheated TiB2 powder is dispersed into molten AA7075 at 850 to improve wettability and distribution. The tensile strength, hardness, wear resistance, and microstructural studies were conducted for the proposed composites. Pin- on-Disc set up was used to study the wear behaviour of the proposed composites. The results revealed that the addition of TiB2 particulates to AL7075 matrix improved all the properties when compared to AL7075 matrix. Worn surface of the abraded surface was analysed using Scanning Electron Microscope.

Keywords: AA7075, Metal matrix composites, TiB ${ }_{2}$, Stir Casting, Corrosion, Properties.

\section{INTRODUCTION}

The AMMCs have excellent properties which finds the applications in the field of automotive, aerospace, etc. due to their improved strength and increased resistance to wear $[1,2]$. The mechanical and tribological properties of AMMC's are enhanced by the addition of reinforcements like $\mathrm{Al}_{2} \mathrm{O}_{3}, \mathrm{SiC}, \mathrm{TiC}, \mathrm{TiB}_{2}, \mathrm{ZrO}_{2} \mathrm{~B}_{4} \mathrm{C}$ etc., [2]. The AMMCs can be manufactured by spray deposition, powder metallurgy, squeeze-casting, compocasting, and stir-casting. Several investigators had adopted stir-casting process for fabrication of AMMCs due to higher metal yield, lesser damage to the particulate reinforcement and cost-effective [3-8]. Among the various ceramic reinforcements, TiB2 particulates have high stiffness, superior hardness and good thermal stability and it emerges as a better reinforcement [7]. The exothermic nature of $\mathrm{TiB} 2-\mathrm{Al}$ reaction and its reduced oxidation during the merging of reinforcement has been a potential wear resistant for composite. Concerning applications of metal matrix composites containing carbide, oxide, boride and nitride are in due choice with good wear resistance. Addition of ceramic particulates in various aluminium matrixes had markedly increased the wear performance of the matrix as stated by many researchers [9-16]. The mutual interactions between the matrix-reinforcement interfaces, the volume, the size or wt. fraction of reinforcement in matrix are the factors which influence the mechanical properties of the composite [11]. Jianxin et al. have emphasized that the reinforcement of $\mathrm{Al}_{2} \mathrm{O}_{3}-\mathrm{TiB}_{2} / \mathrm{SiC}$ composites have increased the resistance to wear property even up to $800^{\circ} \mathrm{C}$. The mode of wear was found to

Received: November 2018, Accepted: May 2019

Correspondence to: M. Ramesh,

Faculty of Mechanical Engineering, K. Ramakrishnan

College of Engineering

E-mail: sastra.ramesh90@gmail.com

doi:10.5937/fmet1904873R

(C) Faculty of Mechanical Engineering, Belgrade. All rights reserved be oxidative wear up to $800^{\circ} \mathrm{C}$, it's found that at higher temperatures the oxidative wear dominates and this oxidation plays a crucial role in evaluating the wear rate [12-14]. Many researchers found that the inhomogeneous distribution of reinforcement particulates on the molten matrix, poor wettability, surface tension and high interfacial energy had reduced the mechanical properties $[15,16]$. The properties of the composites can be increased by preheating the reinforcement for removal of absorbed gas and moisture, usage of surface coatings and addition of alloying elements with inert gas atmosphere, the injection of particles to prevent or reduce the formation of agglomeration and clustering of particles and improve the wettability and distribution in homogeneous form. [17-18].

From the previous literatures, it was found that there were no works related to characterisation and adhesive wear studies of AA7075- xTiB2. In this work, the AA7075- xTiB2 composites through stir-casting process with varying percentages $(0,4,8 \& 12$ wt. \%) of TiB2 were synthesised, and the fabricated composites were characterized for porosity, mechanical, microstructure and wear behaviour. The scope of this present work is to understand and analyse the correlation between mechanical, wear behaviour and microstructure of AA7075xTiB2 composites.

\section{EXPERIMENTAL DETAILS}

In this study, AA7075 alloy was used as a matrix material, and its chemical composition is shown in Table 1. It was reinforced by different amounts of TiB2 particles $(4,8,12$ wt.\%) via an in-situ reaction. In synthesis process of the composite, the A17075 ingot was machined and cut into small blocks. The quantity of matrix to be melted is measured with added $25 \%$ slag, evaluated through trial and error method. Aluminium 7075 alloy was melted using an induction furnace with a graphite crucible at the centre for $850^{\circ} \mathrm{C}$ for 20 mins. 
Meanwhile, the TiB2 powder is preheated at $500^{\circ} \mathrm{C}$ and calcium globules $\left(5 \mathrm{wt} \%\right.$ ) were preheated to $150{ }^{\circ} \mathrm{C}$. The molten Al7075 was allowed to cool down to $750{ }^{\circ} \mathrm{C}$ to form slurry. The stirring was carried for $10 \mathrm{mins}$ at $500 \mathrm{rpm}$ using four blade stirrer. A vortex is formed due to the stirring process. The preheated $\mathrm{TiB}_{2}$ particles were fed through a hopper to the vortex with proper timing. The furnace temperature was controlled around $750{ }^{\circ} \mathrm{C}$ with continued stirring to give a homogeneous mixture. The molten mixture is formed into rods and plates by cooling the mould at room temperature. The tensile and hardness specimens were fabricated according to ASTM E08 and ASTM E384-11 standards. The sliding wear tests of $\mathrm{Al} 7075-\mathrm{xTiB}_{2}$ were carried out according to ASTM G99 standards.

The microstructure and worn surface morphology of the abraded surface was studied in Scanning Electron Microscope (SEM), along with an Energy Dispersive Spectroscopy (EDS) to examine the particle distribution and interfaces of the composites. The specimens were prepared by grinding with 1000 and 2000 grit papers and then polished by standard metallographic procedure. Density plays a vital role in determining the weight of the components. The theoretical densities of the composite were obtained by the Rule of Mixture (ROM)

Table 1. Composition of Al7075 alloy

\begin{tabular}{|c|c|c|c|c|c|c|c|c|}
\hline Component & $\mathrm{Al}$ & $\mathrm{Cr}$ & $\mathrm{Cu}$ & $\mathrm{Mg}$ & $\mathrm{Fe}$ & $\mathrm{Si}$ & $\mathrm{Ti}$ & $\mathrm{Zn}$ \\
\hline wt. \% & 89.07 & 0.23 & 1.6 & 2.5 & 0.5 & 0.4 & 0.2 & 5.5 \\
\hline
\end{tabular}

\section{RESULTS AND DISCUSSIONS}

\subsection{Characterization of composites}

Figure 1 shows the SEM image of $4 \%$ of $\mathrm{TiB}_{2}$ particulates reinforced Aluminium 7075 alloy matrix comosites.

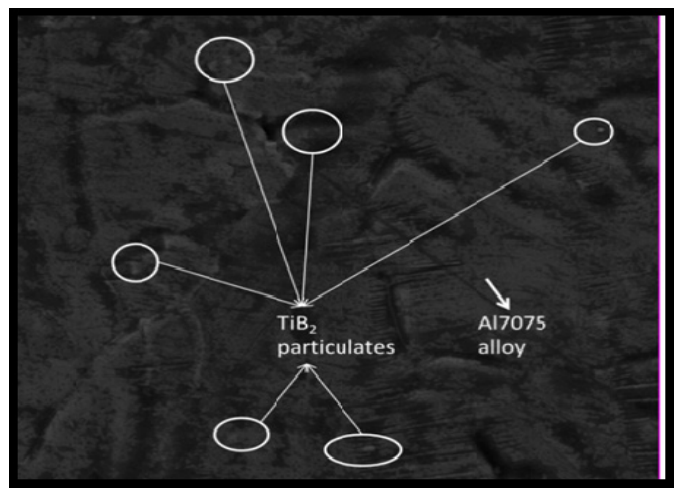

Figure 1. SEM images shows the presence of TiB2 particulates in the matrix Al7075 alloy.

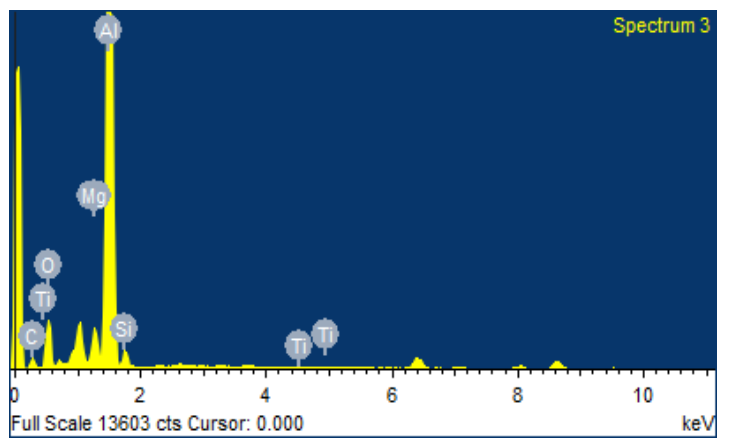

Figure 2. EDS image of Al7075 alloy
From the EDS image in figure 2, the peak values of Aluminium and Titanium have been seen, which shows the content of particulates of produced comosites. The EDS image of $\mathrm{Al} 7075 / 4 \% \mathrm{TiB}_{2}$ composite is shown in Figure 2 which confirms the presence of Aluminium and Titanium particulates.

\subsection{Effect of reinforcement on density}

Figure 3, shows the theoretical and experimental densities of various wt. \% of TiB2 in Al 7075 composites. The density increases with increase in TiB2 in Al 7075 composites. From the Figure 3, it can be seen that there is an increase in values of density when TiB2 content was increased in Al7075 composites. The values of theoretical density values were higher because the theoretical density value does not consider porosity during the stir casting process. Thus the addition of $12 \mathrm{wt}$. \% TiB2 to Al 7075 resulted in better density values, and pure $\mathrm{Al} 7075$ resulted in least density values.[19-21]. The presence of porosity is due to the mixing of TiB2 in Al7075 makes density difference between the matrix and reinforcement. The presence of porosity in the manufactured composites is due to (i) gas entrapment during the stir casting process, (ii) increase in air contact ratio with the surface area, (iii) shrinkage during the solidification process and (iv) pouring distance from the mould.

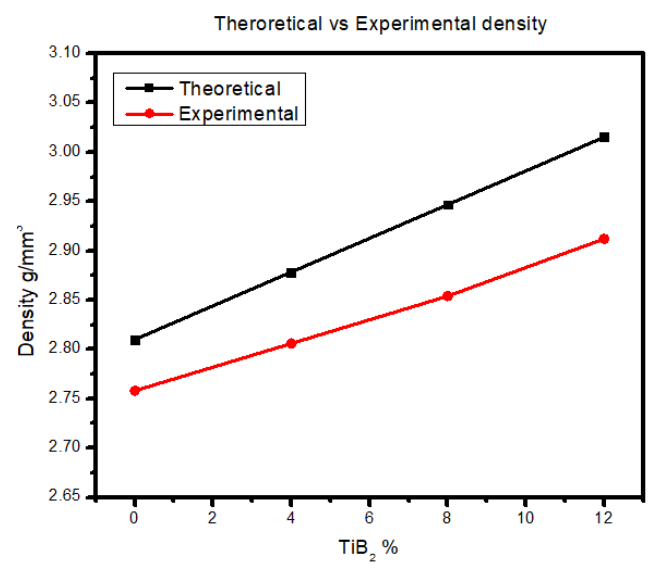

Figure 3. Theoretical and Experimental density for various weight percentage of TiB2 reinforcement

\subsection{Effect of reinforcement on tensile strength}

Figure 4 shows the A17075 and A17075 composites with various wt. $\%$ of TiB2. The tensile load is provided to develop strong internal stresses, which may fail when it increases above the strength of the material. The internal stress distribution will be based on the reinforcement particles bonding [22]

From Figure 4, it can be inferred that the tensile strength increases when TiB2 was increased in A17075 composites. The tensile strength of Al7075 is $198 \mathrm{MPa}$ and the tensile strength increases as the increasing reinforcement percentage of $\mathrm{TiB}_{2}$, where it obtains a $17 \%$ increase on 4 wt. $\%$ of $\mathrm{TiB}_{2}$ further it reached up to $29 \%$ for the 12 wt. $\%$ of $\mathrm{TiB}_{2}$ reinforcement, but the percentage difference of UTS between 8 and 12 wt. \% of reinforcement is minimum. The increase in tensile strength at $12 \mathrm{wt}$. \% is due to better bonding between TiB2 and Al7075 matrix [7, 24]. 


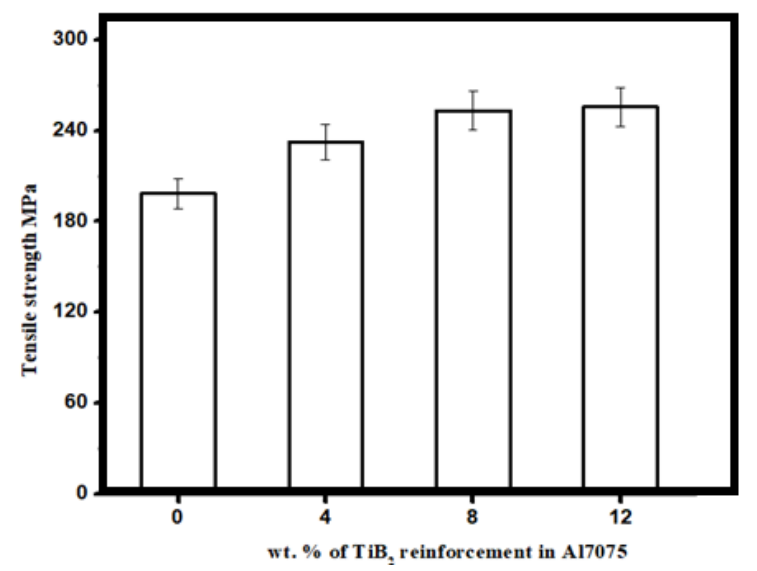

Figure 4. Tensile strength for various weight percentage of TiB2 reinforcement

\subsection{Effect of reinforcement on hardness}

In general, hardness can be viewed as the resistance to indentation. The hardness of A17075 and Al7075 composites are shown in Figure 5. This is evident as shown in Figure 5, where the micro-hardness values of the samples show a pronounced improvement when TiB2 content was increased. When TiB2 was added at 4wt. $\%$ the hardness values improved by $19.5 \%$ compared to pure Al 7075. Furthermore, it increased by $32.6 \%$ and $42.4 \%$ from the base matrix with 8 wt. $\%$ and 12 wt. $\%$ of added reinforcement. The higher hardness and stiffness of TiB2 particles gives a good resistance to plastic deformation on A17075 matrix; the TiB2 particles form preferable sites of heterogeneous nucleation of grains when added in melt matrix. Therefore, the microstructure of matrix is refined, and bonding improves, which is a major factor for improving hardness. Similarly, many researchers reported the improvement in Vickers hardness value when TiB2 particles was added through in-situ process in any metallic matrix $[22,25,26]$.

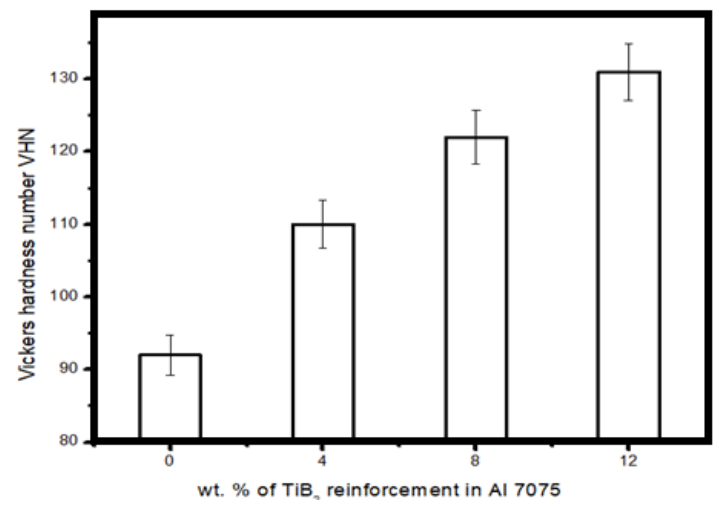

Figure 5. Peak Hardness values of Al7075 cast alloy with $4 \%, 8 \%$ and $12 \%$ TiB2 reinforcement

\subsection{Effect reinforcement on wear properties}

Figures $6(\mathrm{a}-\mathrm{c}), 7(\mathrm{a}-\mathrm{c})$, and $8(\mathrm{a}-\mathrm{c})$ show the wear rate of Al7075 composites as a function of weight percentage of TiB2, load, and speed. Figure 6 (a-c) shows the wear rate of various percentage of $\mathrm{TiB}_{2}$ reinforcements in $\mathrm{Al}$ 7075 matrix at constant sliding speed. Generally, the wear rate increases when the load applied is increased. The wear rate of pure Al 7075 composite is higher when compared to other composites produced. The values of wear rate started to decrease when the amount of $\mathrm{TiB}_{2}$ reinforcements in Al 7075 matrix was increased, which can be seen from the figure. The same trend was noted for all sliding speeds.[25, 27,28].

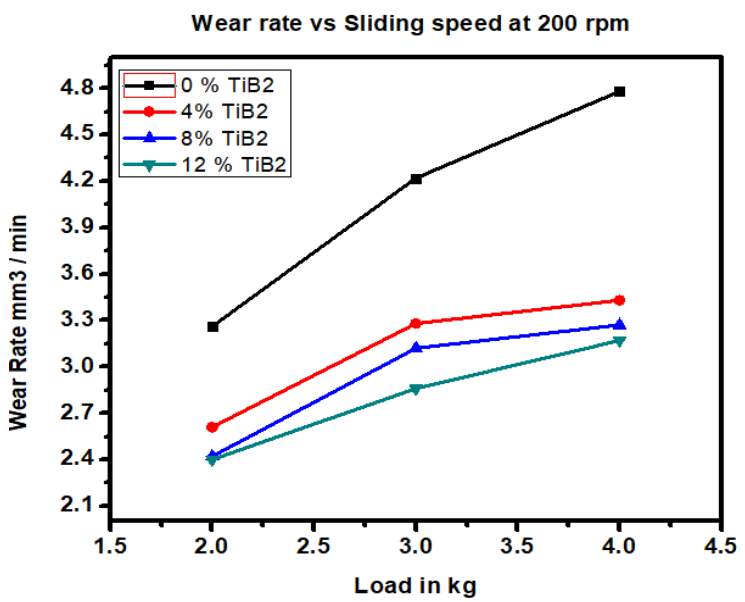

(A)

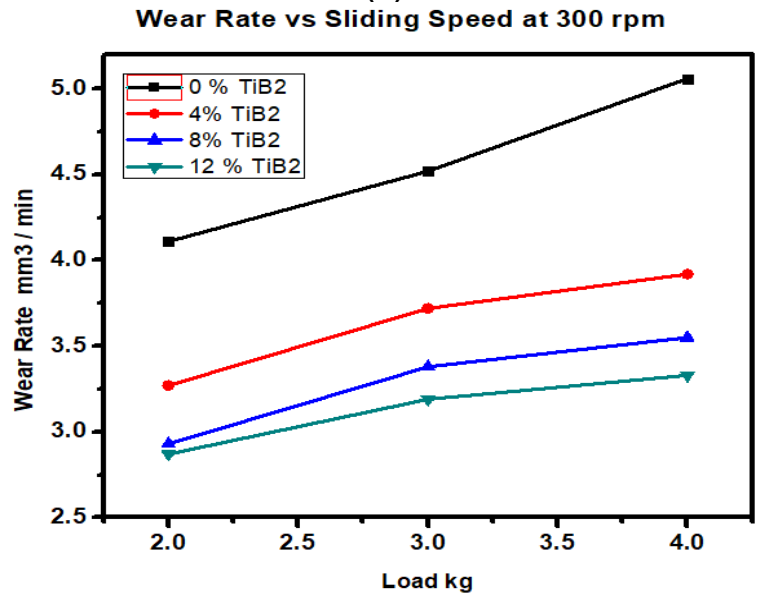

(B)

Wear Rate vs Sliding speed at $400 \mathrm{rpm}$

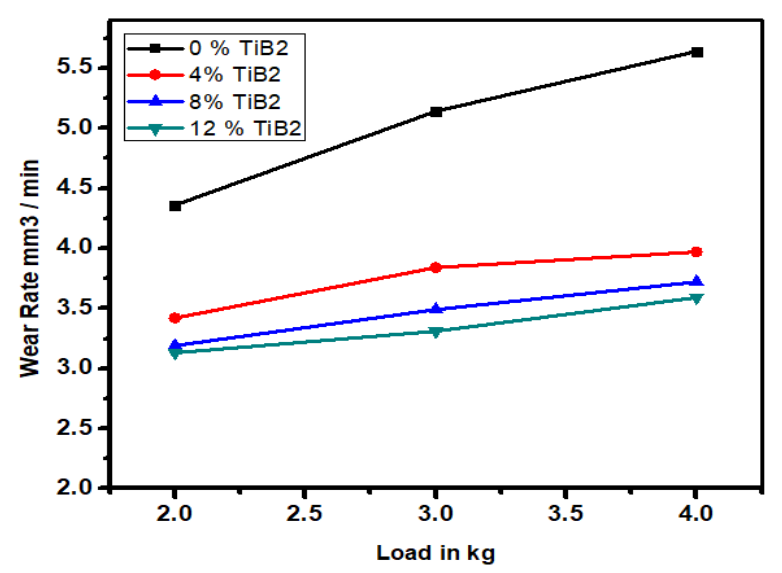

(C)

Figure 6. (a-c) Effect of Wear Rate at different loading conditions with different sliding speed for various composition of composites

The wear rate difference of $30-35 \%$ is shown in the graphs of base alloy and $12 \% \mathrm{TiB}_{2}$ addition of all loads. The wear rate graph is not linear with the increase in reinforcement of $\mathrm{TiB}_{2}$, which is stated in Mandal et al. 
due to complex processes that occurred during wear of the composites. At $200 \mathrm{rpm}$ sliding speed, the wear rate at different loads depicts that wear at lower loads is less, when compared at higher loads. The wear rate interaction between the counterface and matrix will be attributed based on the reinforcement. The phenomena of adhesion are created between the asperity to asperity contact of the hard counterface (disc) and the soft surface (pin). This contact undergoes deformation due to the results of cold welding and is termed as adhesion. This process results in metal loss as asperities are detached from the surface during sliding and is termed as adhesive wear.

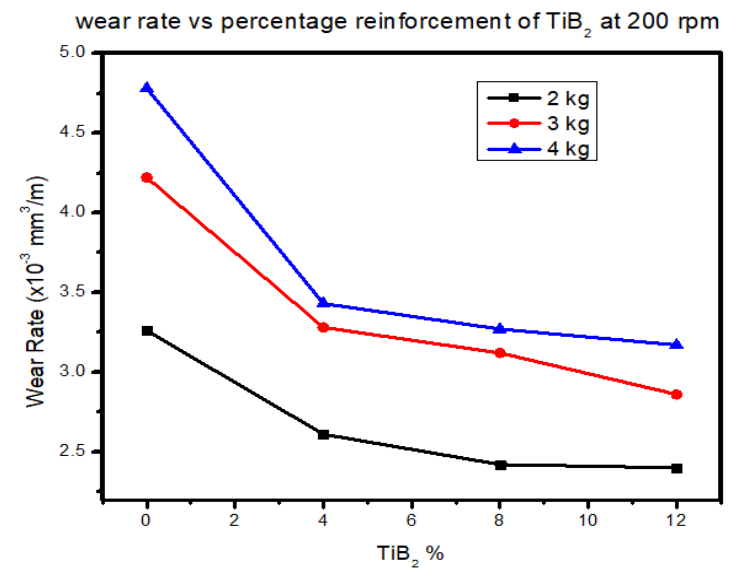

(A)

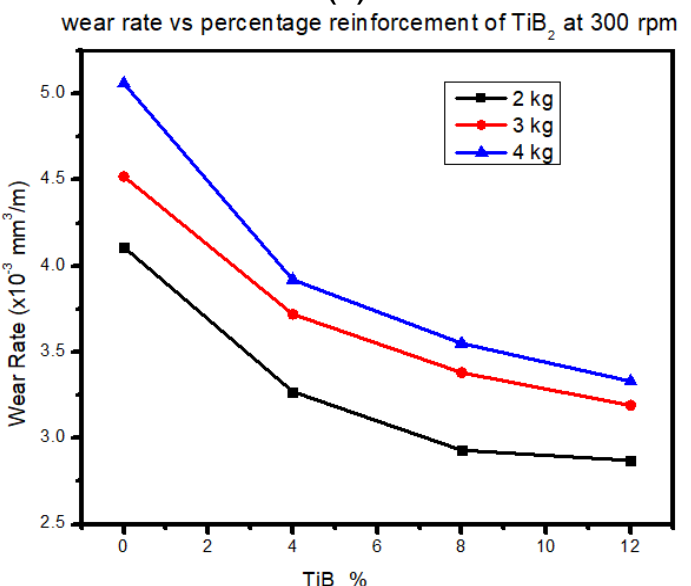

(B)

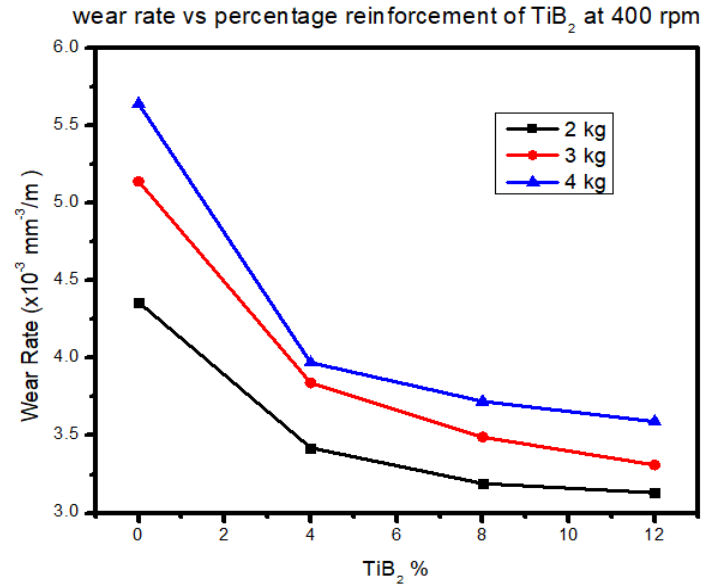

(C)

Figure 7 (a-c) Effect of Wear Rate at different composition of TiB2 particulate reinforcement and at different loading conditions for different sliding speed
The resistance to wear is termed by the reciprocal of wear rate of the composites. It is based on the function of load applied, and TiB2 particulates present for a constant sliding speed for 20 mins. From the Figures 8 a, b $\& \mathrm{c}$, the influence of $\mathrm{TiB}_{2}$ on the part of wear resistance at lower load is more significant, and the wear resistance drops as the applied load is increased to $4 \mathrm{~kg}$. The obtained graph is also not linear as the variation of processing and adhesion properties influences the composites wear resistance.

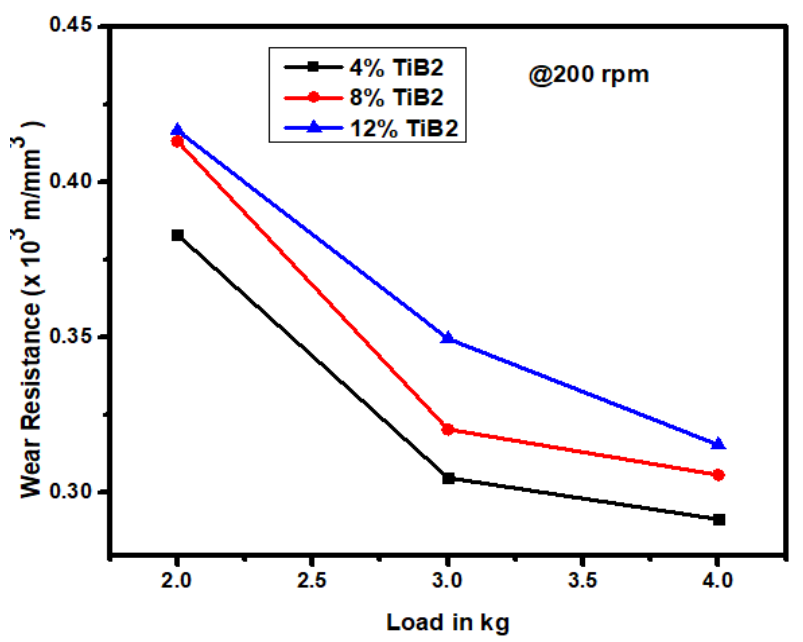

(A)

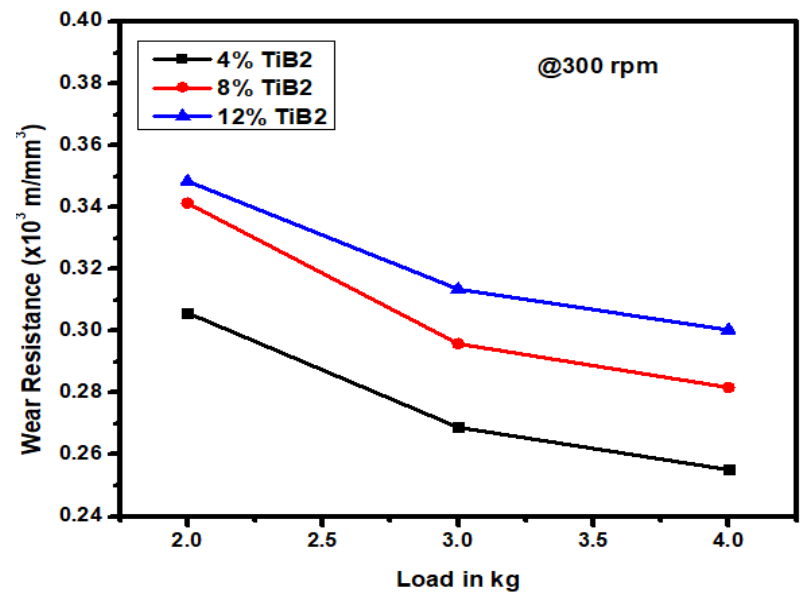

(B)

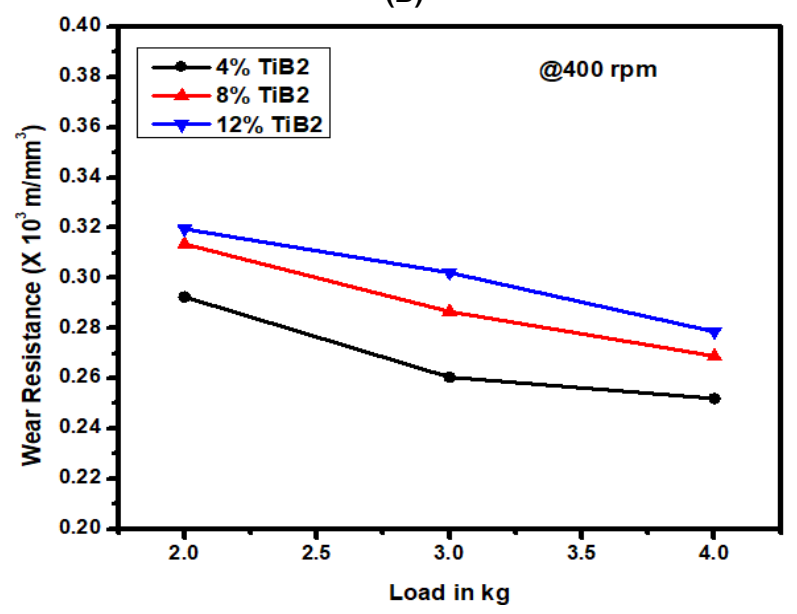

(C)

Figure 8 (a-c) Effect of Wear Resistance at different composition of TiB2 particulate reinforcement and at different loading conditions for different sliding speeds. 
As said in Archard's law of sliding wear, "the hardness is directly proportional to the volumetric wear resistance of the composites". The wear resistance of the 8 wt. $\% \mathrm{TiB}_{2}$ and 12 wt. $\% \mathrm{TiB}_{2}$ was similar with significant increase at $2 \mathrm{~kg}$ of applied load, but the resistance came down at $3 \mathrm{~kg}$ of load. The wear rate obtained per unit wt. $\%$ of $\mathrm{TiB}_{2}$ particulate reinforcement is a vital factor in wear analysis due to its drastic changes as there is an increase in the amount of reinforcement. A study of worn surface morphology and surface is important for better understanding of the nonlinear graphs observed in these specimens [27].

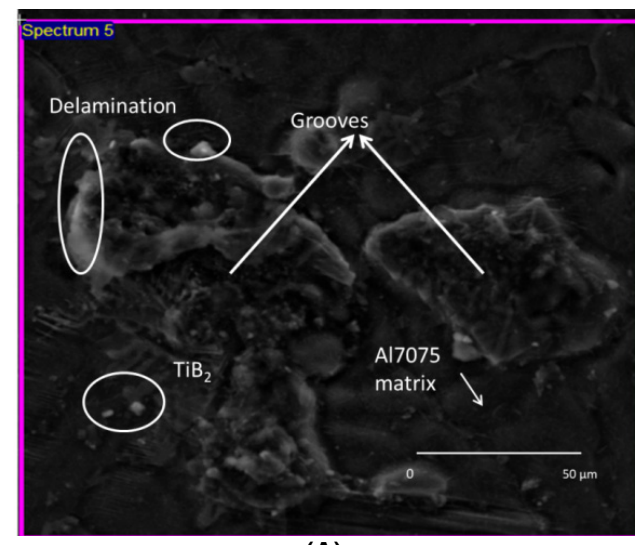

(A)

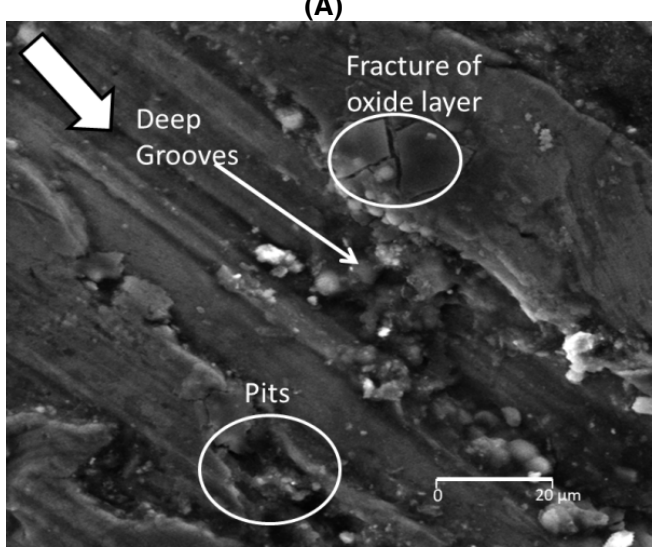

(B)

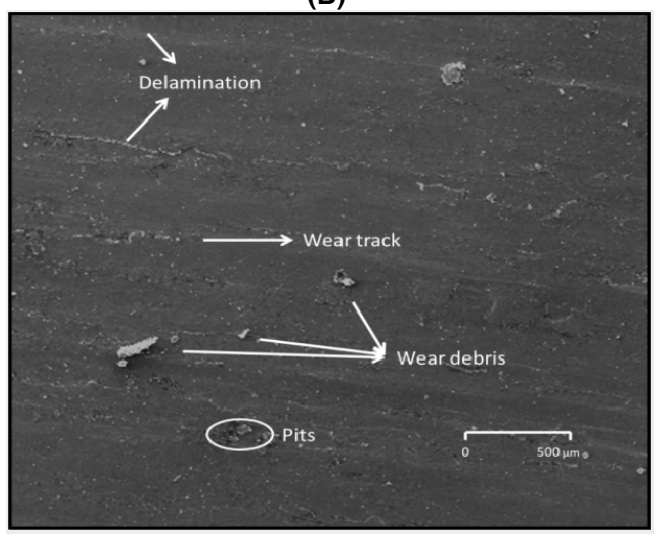

(C)

Figure 9 (a) SEM image of the wear surface of $12 \%$ reinforcement of TiB2 (b) SEM image of the wear surface for the specimen at $4 \mathrm{Kg}$ Load, (c) SEM image of the wear surface for the specimen at $2 \mathrm{Kg}$ Load

Figures 9 a -9 c show SEM image of the worn surface of $\mathrm{TiB}_{2}$ reinforced $\mathrm{Al} 7075$ alloy, the specimen samples. The samples were made to slide under room temperature with different loads of 2,3 and $4 \mathrm{Kg}$.
Initially, the specimens were cleaned with chemical acetone to remove loose particles like debris, and many scratches were seen on the wear surface. This scratch indicates the abrasive wear's primary wear mechanism. The wear mechanism depicts the plastic deformation of surfaces, due to the relative motion of contact surface, pressure, the asperities and surface projections present.

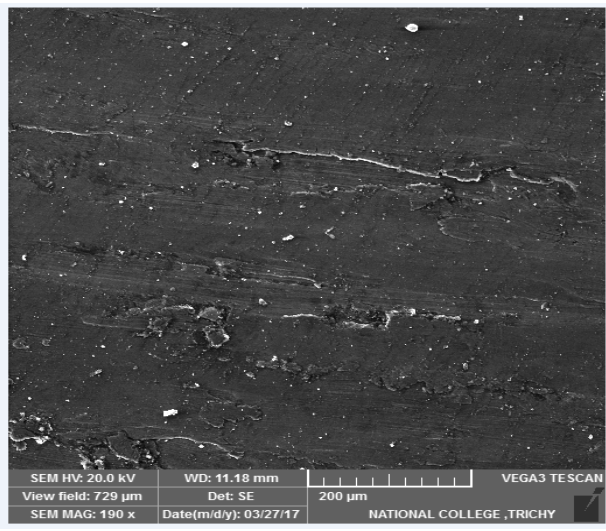

(A)

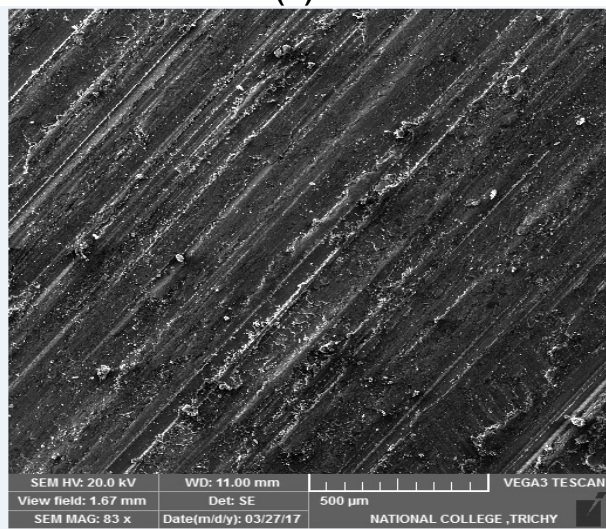

(B)

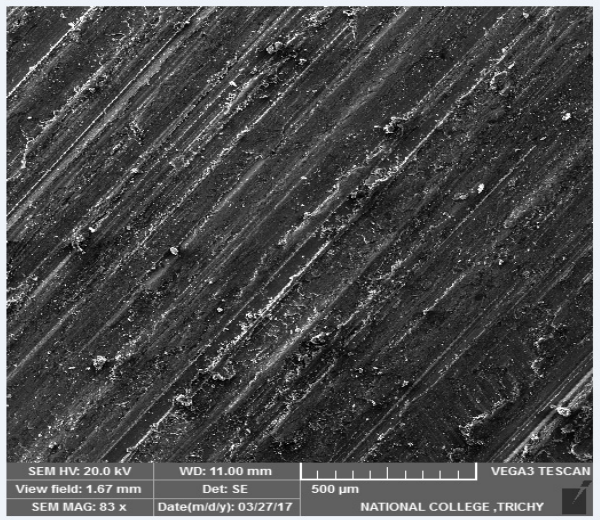

(C)

Figure 10 (a) SEM image of the wear track for specimen with $4 \%$ TiB2 reinforcement at $4 \mathrm{Kg}$ load condition, (b) specimen with $8 \%$ TiB2 reinforcement at $4 \mathrm{Kg}$ load condition, (c) wear track for specimen with $12 \%$ TiB2 reinforcement at $\mathbf{4} \mathbf{~} \mathrm{g}$ load condition

The wear rate examination reveals the pattern of grooves, tracks, asperities and ridges running parallel on the surface along the sliding direction, as shown in Figure 10 a to $10 \mathrm{c}$. The aggressiveness of grooves is larger and deeper in lower amount of reinforced composite than the higher reinforcement as the factor of loading increases $[25,26]$. The grooves formed on the low $\mathrm{TiB}_{2}$ reinforcement matrix are coarser than the grooves which are smoother, found on the $12 \% \mathrm{TiB}_{2}$ 
addition. The presence of thin oxide film near the wear tracks was seen and reveals the layer of oxide debris present on the wear surfaces. There were not many fractured micro cracks seen in these SEM images as stated by Degnan et al. [7,8]. Large craters were formed in the specimen due to the tearing of larger debris during sliding condition, and in the process, the reinforcement $\mathrm{TiB}_{2}$ particles adhere to the larger debris.

\section{CONCLUSION}

In the current research work, various percentage of reinforcements of $\mathrm{TiB}_{2}$ added to $\mathrm{Al} 7075$ were synthesised by stir casting technique. The tensile, hardness and tribological properties were studied. The following conclusions were reported.

1. The preheating of the $\mathrm{TiB}_{2}$ particles before the melt stirring has some significant effect. The porosity is at reduced level, which shows the bonding was fairly better.

2. The values of microhardness increased when the addition of $\mathrm{TiB}_{2}$ particles increased in the A17075 matrix.

3. The highest wear resistance and lowest wear rate was obtained by the samples processed in $2 \mathrm{Kg}$ load and at $200 \mathrm{rpm}$ speed with $12 \%$ addition of reinforcement.

4. There was an increase in wear resistance at $12 \mathrm{wt}$. $\%$ TiB2 in A17075 composites irrespective of applied load, sliding velocity and sliding distance.

5. The worn surface morphology reveals more wear grooves during high load irrespective of sliding distance and wt. $\%$ of TiB2 reinforcement.

\section{REFERENCES}

[1] Atrian, A., et al. "A comparative study on hot dynamic compaction and quasi-static hot pressing of A17075/SiC np nanocomposite." Advanced Powder Technology 26.1 (2015): 73-82.

[2] Li, Peijie, E. G. Kandalova, V. I. Nikitin. "In situ synthesis of $\mathrm{Al}-\mathrm{TiC}$ in aluminum melt." Materials Letters 59.19-20 (2005): 2545-2548.

[3] Akbari, M. Karbalaei, H. R. Baharvandi, and O. Mirzaee. "Nano-sized aluminum oxide reinforced commercial casting A356 alloy matrix: Evaluation of hardness, wear resistance and compressive strength focusing on particle distribution in aluminum matrix." Composites Part B: Engineering 52 (2013): 262-268.

[4] Kaushik, N. Ch, and R. N. Rao. "Effect of grit size on two body abrasive wear of Al 6082 hybrid composites produced by stir casting method." Tribology International 102 (2016): 52-60.

[5] [5] Sajjadi, Seyed Abdolkarim, H. R. Ezatpour, and $\mathrm{H}$. Beygi. "Microstructure and mechanical properties of $\mathrm{Al}-\mathrm{Al} 2 \mathrm{O} 3$ micro and nano composites fabricated by stir casting." Materials Science and Engineering: A 528.29-30 (2011): 8765-8771.

[6] Pazhouhanfar, Y., and B. Eghbali. "Microstructural characterization and mechanical properties of TiB 2 reinforced Al6061 matrix composites produced using stir casting process." Materials Science and Engineering: A 710 (2018): 172-18

[7] Ramesh, C. S., et al. "Development of Al 6063TiB2 in situ composites." Materials \& Design 31.4 (2010): 2230-2236.

[8] Chelliah, Nagaraj M., Harpreet Singh, and M. K. Surappa. "Correlation between microstructure and wear behavior of AZX915 Mg-alloy reinforced with $12 \mathrm{wt} \%$ TiC particles by stir-casting process." Journal of Magnesium and Alloys 4.4 (2016): 306-313

[9] Emamy, M., M. Mahta, J. Rasizadeh. "Formation of TiB 2 particles during dissolution of TiAl 3 in AlTiB 2 metal matrix composite using an in situ technique." Composites science and Technology 66.7 (2006): 1063-1066.

[10] Kumar, S., V. Subramanya Sarma, B. S. Murty. "High temperature wear behavior of $\mathrm{Al}-4 \mathrm{Cu}-\mathrm{TiB} 2$ in situ composites." Wear 268.11 (2010): 1266-1274.

[11] Pazhouhanfar, Y., and B. Eghbali. "Microstructural characterization and mechanical properties of TiB 2 reinforced Al6061 matrix composites produced using stir casting process." Materials Science and Engineering: A 710 (2018): 172-180.

[12] Jianxin, Deng. "Friction and wear behaviour of $\mathrm{A} 12 \mathrm{O} 3 / \mathrm{TiB} 2 / \mathrm{SiCw}$ ceramic composites at temperatures up to 800 C." Ceramics international 27.2 (2001): 135-141.

[13] Jianxin, Deng, Ai Xing, Li Zhaoqian. "Friction and wear behavior of A12O3/TiB2 composite against cemented carbide in various atmospheres at elevated temperature." Wear 195.1-2 (1996): 128-132.

[14] Jianxin, Deng, Ai Xing. "SiC whisker reinforced A12O3/TiB2 ceramic composites." Chin Ceram Soc 23.4 (1995): 385-392.

[15] Shirvanimoghaddam, K., et al. "Boron carbide reinforced aluminium matrix composite: Physical, mechanical characterization and mathematical modelling." Materials Science and Engineering: A 658 (2016): 135-149.

[16] Auradi, V., et al. "Processing of B 4 C Particulate Reinforced 6061Aluminum Matrix Composites by Melt Stirring Involving Two-step Addition." Procedia Materials Science 6 (2014): 1068-1076.

[17][17] Sajjadi, Seyed Abdolkarim, H. R. Ezatpour, and M. Torabi Parizi. "Comparison of microstructure and mechanical properties of A356 aluminum alloy/A12O3 composites fabricated by stir and compo-casting processes." Materials \& Design 34 (2012): 106-111.

[18] Sajjadi, Seyed Abdolkarim, et al. "Fabrication of A356 composite reinforced with micro and nano Al2O3 particles by a developed compocasting method and study of its properties." Journal of Alloys and Compounds 511.1 (2012): 226-231.

[19] Kok, M. "Production and mechanical properties of A12O3 particle-reinforced 2024 aluminium alloy composites." Journal of Materials Processing Technology 161.3 (2005): 381-387. 
[20] Kumar, B. Praveen, A. K. Birru. "Microstructure and mechanical properties of aluminium metal matrix composites with addition of bamboo leaf ash by stir casting method." Transactions of Nonferrous Metals Society of China 27.12 (2017): 2555-2572.

[21] Hashim, J., L. Looney, and M. S. J. Hashmi. "Metal matrix composites: production by the stir casting method." Journal of materials processing technology 92 (1999): 1-7.

[22]Han, Yanfeng, Xiangfa Liu, and Xiufang Bian. "In situ TiB2 particulate reinforced near eutectic Al-Si alloy composites." Composites Part A: Applied Science and Manufacturing 33.3 (2002): 439-444.

[23] Natarajan, S., et al. "Sliding wear behaviour of Al $6063 / \mathrm{TiB} 2$ in situ composites at elevated temperatures." Materials \& Design30.7 (2009): 2521-2531.

[24] Mandal, A., B. S. Murty, M. Chakraborty. "Sliding wear behaviour of T6 treated A356-TiB2 in-situ composites." Wear266.7-8 (2009): 865-872.

[25] Mandal, A., M. Chakraborty, B. S. Murty. "Effect of TiB2 particles on sliding wear behaviour of Al4Cu alloy." Wear262.1-2 (2007): 160-166.

[26] Alpas, A. T., J. D. Embury. "Sliding and abrasive wear behaviour of an aluminum (2014)-SiC particle reinforced composite." Scripta Metallurgica et Materialia 24.5 (1990): 931-935.

[27] Kannan, C., Ramanujam, R., 2017. Comparative study on the mechanical and microstructural characterisation of AA 7075 nano and hybrid nanocomposites produced by stir and squeeze casting. Journal of advanced research, 8(4), pp.309-319.
[28] K. Krishnamurthy, M. Ashebre, J. Venkatesh, B. Suresha „Dry Sliding Wear Behavior of Aluminum 6063 Composites Reinforced with TiB2 Particles“" Journal of Minerals and Materials Characterization and Engineering, 2017, 5, 74-89.

\section{ИСТРАЖИВАЮЕ МЕХАНИЧКИХ СВОЈСТАВА И ХАБАЊА КОД КОМПОЗИТА ОЈАЧАНИХ ТИТАНДИБОРИДОМ}

\section{М. Рамеш, Ј. Данијел Д., М. Равичандран}

Композити са матрицом од алуминијума су материјали који се све више користе у авио и аутомобилској индустрији због побољшаног односа снаге и тежине, боље отпорности на корозију и бољих триболошких својстава. У овом раду је легура АА 7075 ојачана честицама титанборида $(0,4$, 8, 12 теж. \%) процесом изливања мешањем. Претходно загрејани прах титандиборида је распршен у истопљени АА7075 на температури од $850^{\circ}$ Ц да би се побољшала влажност и дистрибуција честица. Затезна чврстоћа, тврдоћа, отпорност на хабање и микроструктурна испитивања су извршена код композитног материјала. Трибометар пин-он-диск је коришћен за испитивање пнашања хабања. Резултати су показали да се додавањем честица титандиборида композиту са матрицом од алуминијума побољшавају његова својства. Скенирајућим електронским микроскопом извршена је анализа похабане површине. 